\title{
Evli Bireylerin Aldatma Eğilimi ile Büyüklenmeci Narsisistik Kişilik Özellikleri Arasındaki İlişkinin İncelenmesi
}

\author{
DOI: 10.26466/opus.936933
}

\author{
* \\ Lütfiye Kaya Cicerali* ${ }^{*}$ Arzu Büyük** \\ * Dr. Öğr. Üyesi, Nişantaşı Üniversitesi, İstanbul/Türkiye \\ E-Posta: kayalut@hotmail.com \\ ORCID: $\quad \underline{0000-0002-8444-2847}$ \\ ${ }^{* *}$ Klinik Psikolog, İstanbul, Türkiye \\ E-Posta: buyukarzu@gmail.com \\ ORCID: $\underline{0000-0001-6592-2258}$
}

\section{Öz}

2019 yılında verileri toplanan bu araştırmada evli bireylerde aldatma eğilimi ile büyüklenmeci narsisizm arasındaki ilişki araştırllmıştır. Araştırmanın örneklemi kolaylık örneklemsine göre oluşmuş, 18 yaş ve üzerinde, en az bir yıldır evli, en az ilkokul mezunu 60 bireyden mütevellittir. Katıllmcılara Kişisel Bilgi Formu, Aldatma Eğilimi Ölçeği ve Narsisistik Kişilik Envanteri uygulanmıştır. Çalışmada katılımoların cinsiyetleri açısından aldatma eğilimi puanları istatistiksel olarak anlamlı biçimde farklı bulunmuştur; kadın katılımcıların aldatma eğilimi erkeklere göre daha yüksektir. Çalışmada kadın ve erkek bireylerin büyüklenmeci narsisizm puanlarını benzer düzeyde oldukları, birbirlerinden anlaml biçimde farklılaşmadıkları saptanmıştır. Çalışma sonucunda aldatma eğilimi ile büyüklenmeci narsisizm arasında anlamlı bir iliş̧ki bulunamamıştır. Diğer taraftan, büyüklenmeci narsisizmin altı alt boyutundan biri olan hak iddia etme ile aldatma eğilimi arasında orta derecede kuvvetli, pozitif yönde anlaml ilişki saptanmıştır. Hak iddia etme kişilik boyutu artııkça aldatma eğilimi de artı̧̧ göstermektedir. Sonuçlar tartışılıı̧̧, aile/çift terapisi uygulamalarında görev yapan mental sağlık çalı̧anlarına ve bu konuda çalışan araştırmacılara konuyla ilgili önerilerde bulunulmuştur.

Anahtar Kelimeler: Aldatma Ĕ̆ilimi, Büyüklenmeci Narsisizm, Aldatma, Patolojik Narsisizm, Çift Terapisi. 


\title{
A Study on the Link between the Tendency to Cheat and Adaptive Narcissistic Personality Characteristics in Married Individuals
}

\begin{abstract}
In this study, which was carried out in 2019, the relationship between intramarital cheating tendency and grandiose narcissism was investigated. The participants were aged 18 and older. The Personal Information Form, the Cheating Tendency Scale and the Narcissistic Personality Inventory were administered. The results indicated gender difference was significant in that females had higher cheating tendency than males. However, male and female grandiose narcissism scores did not differ significantly. Against expectations, a significant relationship between cheating tendency and grandiose narcissism was not found, either. On the other hand, a moderately strong, significant positive relationship was found between entitlement and cheating tendency, as entitlement increased cheating tendency increased, as well. Discussion of results included suggestions for researchers and mental health professionals who work on cheating problems with couples and families.
\end{abstract}

Key Words: Deception Tendency, Grandiose Narcissism, Deception, Pathological Narcissism, Couple Therapy. 


\section{Giriş}

Evli bireyler arasında sadakat oldukça önemli bir konu olabilmektedir. İlişkide istikrar ve açılık bireylerin eşlerinde olmasını istediği özelliklerin başında gelir (Bradbury ve Fincham, 1988). Buna rağmen aldatma sıklıkla rastlanan bir sorun olarak karşımıza çıkabilmektedir.

Literatürde aldatma; birbirine bağlılık göstereceklerine dair anlaşmış olan bireylerin, ilişkileri haricinde bir kişiye karşı duygusal, düşünsel ve davranışsal tutumlarının ilişkiyi tehdit edecek biçimde yakınlık içermesi şeklinde tanımlanmaktadır (Atwood ve Schwartz, 2002). Bu bağlamda aldatma sorunu değerlendirilirken evlilik dışı ilişkinin türü, saldırgan eşin kişilik bozukluğu olup olmadığı, eşlerin evlilik algıları ve eşinin evli kalma taahhüdü hakkında eşlerin varsayımları, evlilikte alkolizm veya hipoaktif cinsel istek benzeri durumlar ve şikayetler göz önünde bulundurulması gereken faktörler olarak belirtilmektedir. Bu faktörler arasında dinamik bir etkileşim olduğu vurgulanmaktadır (Bagarozzi, 2014). Bütün bu faktörler değerlendirilmeden aldatmanın yarattığı hasarla baş etmek güçleşebilir.

Eşlerden biri tarafından evlilik dışı ilişkinin tespit edilmesi, çiftlerin evlilik terapisine gelmesine neden olan tetikleyici faktör olabilmektedir. Çiftlerle yapılan çalışmalarda, kadınların sırasıyla ilgisizlik, aldatma ve alkol kullanımı; erkeklerin sırasıyla aldatma, cinsel sorun ve iletişim sorunu konularında sıklıkla yardım aldığı tespit edilmiştir (Set, 2019). Bu bağlamda aldatma sorununun psikopatoloji çerçevesinde araştırılmasının çiftlerle yapılan terapi çalışmalarına oldukça katkı sunacağ 1 düşünülmektedir.

Aldatma tek bir nedene bağlanamayan bir sorun olarak tanımlanabillir. Birbirini etkileyen iç içe geçmiş çoklu nedenlerin kişiyi aldatmaya itebileceği belirtilebilir. Yenilik ihtiyacı, özgürlük ve özerk olma ihtiyacı, heyecan arayışı, cinsel gerilime ihtiyaç duyma, varlığının görülmesi, kabul edilmesi ve onaylanması ihtiyacı, aşık olma, kendinden sıkılma, bir başkasıyla yeni bir kendilik versiyonu deneyimleme isteği, 'hayatta hissetme' ihtiyacı, arzulanma ihtiyacı, boşluk hissini doldurma ihtiyacl, özel, önemli ve değerli hissetme ihtiyacı, yetişkin olma hissini yeniden tatmak, çocuk/ebeveyn gibi değil erkek/kadın gibi hissetme arzusu, sahip olamayacağına duyulan doğal çekim, kayıpları telafi etme 
çabası, yaşanamamış ergenlik, benlik parçalarını tamamlama arzusu, stresle başa çımak amacıyla, ilişkisindeki cinsel/duygusal tatminsizlik, bazen de sadece koşulların uygun olmasının kişiyi aldatmaya itebileceği vurgulanmaktadır (Öncü, 2017). Öte yandan aldatma nedenlerinin bir kısmı da kişinin ego zayıflıklarına bağlanabilmektedir (örn. düşük hayal kırıklığg toleransı, zayıf dürtü kontrolü), süperego eksiklikleri (örn. ilkel süperego; ahlak ve vicdan gelişiminin sağlıklı olmaması) ve kendilik sisteminde yapısal anomaliler (örn. bölünmüş kendilik). Bunların dışında herhangi bir kişilik bozukluğu sahibi olmak aldatma davranışı üzerinde etkili olabilmektedir. Belirli ego eksiklikleri, süperego kusurları ve kendilikteki yapısal dinamikler spesifik semptomlar ve savunmalarla birlikte ortaya çıkar (örn. projeksiyon, inkar, bölme) (Kernberg (1995/2011). Bütün bunların yanı sıra çiftlerin bağlanma stilleri (Zareei Mahmoodabadi, 2012) ve erken dönem uyumsuz şemaları (Monajem, Aghayousefi ve Zare, 2013) da ilişkisel problemleri etkilemektedir. Özellikle erken dönemde yaşanan travmalar, yetişkin romantik ilişkilerdeki istikrarı olumsuz yönde etkilemektedir. Yapılan bir çalışmada çocukluk çağı travmalarının romantik ilişkilerdeki aldatma eğilimini artırdığı belirtmektedir (Çavuşoğlu, Kaya, Türkmenoğlu ve Aydin, 2010). Erken dönem uyumsuz şemalar ile aldatma eğilimi arasındaki ilişkiye bakıldığında erkeklerde aldatma eğilimi ile zedelenmiş özerklik şema alanı arasında ilişki olduğu, anneye dair aşırı izin verici/sınırsız ebeveynlik ve babaya dair aşırı izin verici/sınırsız, cezalandırıcı ebeveynlik algısının aldatma eğilimini yordadığı saptanmıştır. Aynı çalışmada kadınların aldatma eğilimi ile kopukluk/reddedilmişlik şema alanı arasında ilişki olduğu, anneye dair aşırı izin verici/sınırsız ebeveynlik ve babaya dair aşırı izin verici/sınırsız ebeveynlik algısının aldatma eğilimini yordadı̆̆ (Tortamiş, 2014).

Erken dönemde ebeveynlerle kurulan ilişkide yaşanan tekrarlayıcı travmatik deneyimlerin yetişkinlik dönemindeki yakın ilişkileri etkilediği söylenebilir. $\mathrm{Bu}$ dönemde bakım verenle kurulan bağlanma ilişkisi yetişkinlik dönemindeki ilişki ağını ve davranışlarını belirlemektedir (Bowlby, 1951). Bu bağlamda erken dönemde oluşan uyumsuz şemalar ve narsisizm ilişkisine bakıldığında narsisistik kişilik özelliklerinin en temel şemalarından olan hak görme/büyüklenmecilik şemasının temelinde aşırı 
şımartıc1, aşırı izin verici ve duygusal bakımdan yoksun bırakıcı ebeveynlik stilinin olduğu vurgulanmaktadır (Tortamış, 2014). Gabbard (1989), büyüklenmeci narsisizmin (açık narsisizm) teşhircilik, saldırganlık, empati yoksunluğu, sömürücülük, hak görme ve düşmanca davranımlar ile bağlantılı olduğunu vurgulamaktadır. Gabbard (1989), büyüklenmeci narsisistlerin, agresif ve kibirli olduklarını, yalnızca kendi ihtiyaçlarına cevap verdiklerini, diğerlerine karşı empati yoksunu olduklarını tespit etmiştir. Literatüre bakıldığında büyüklenmeci narsisizm hem olumlu benlik algısı, liderlik ve kısa dönemli ilişkilerde kişilerarası başarı olumlu sonuçlar hem de ilişki problemleri, saldırganlık ve aldatma gibi olumsuz sonuçlarla ilişkili olduğu bulunmuştur (Burnell ve Campbell, 2009).

Kernberg (1995/2011) psikanalitik açıdan narsisistik kişilik yapısı bulunan kişilerin nesne ilişkilerinde derinlikle bağ kuramayacağını ve çok yönlü sapkın, bebeksi eğilimlere sahip olabileceğini vurgulamaktadır. Narsisistik kişiler kişiyi fethedene kadar aşırı ilgi gösterirler daha sonra bu ilgi bir anda yok olur. Bu da onların istikrarlı bir ilişki kuramayacağını göstermektedir. Narsisistik bireyler erken dönemdeki çatışmalarını ilişkilerine yansıttıklarından aşık olma ve bağlanma kapasiteleri oldukça düşüktür. Bunun yanı sıra narsisistik bireylerin aldatma eğilimlerinin çok yüksek olduğu; istikrarlı ve derinlikli ilişkiler kuramadıkları vurgulanmaktadır (Kernberg, 2011).

Gabbard (1989), narsisizmin grandiyöz ya da büyüklenmeci boyutunun hak görmekle ile yakından ilişki olduğunu saptamışlardır. Morf ve Rhodewalt, (2001), büyüklenmeci narsisistik bireylerin temelde özsaygılarında yetersizlik olduğunu ve özsaygılarını yüksek tutmak amacıyla diğer bireyleri aşağılamak ve sömürmek gibi davranışlara başvurduklarını vurgulanmışlardır. Dickinson ve Pincus (2003), büyüklenmeci narsisistlerin, nesne ilişkilerindeki problemleri inkar ettiklerini belirtmişlerdir. Literatür incelendiğinde büyüklenmeci narsist bireylerin özelliklerine bakıldığında hem olumlu benlik algısı, liderlik ve kısa dönemli ilişkilerde kişilerarası başarılı olumlu sonuçlar hem de ilişki problemleri, saldırganlık ve aldatma gibi olumsuz sonuçlar karşımıza çıkmaktadır (Brunell ve Campbell, 2009). Buradan hareketle büyüklenmeci narsisistik kişilik özellikleri barındıran bireylerin aldatma eğilimi gösterecekleri düşünülmektedir. 
Yapılan literatür taramasında, özellikle ülkemizde aldatma eğilimi ve psikopatolojik belirtiler ile ilgili çok sayıda çalışma yapılmasına rağmen, bu çalışmalar içerisinde kişilik bozukluklarının da yer aldığ1 araştırmaların yetersiz olduğu görülmektedir. Bu noktadan hareketle, birçok araştırmada erken dönem uyumsuz şemaların ele alındığı, narsisistik patolojinin büyüklenmeci boyutuna ilişkin çalışmaların ise olmadığı göz önüne alınarak araştırmanın hem gelecekteki olası bilimsel çalışmalara ışık tutması, hem de terapistlerin aldatma sorunu olan bireyin kişilik dinamiklerini; narsisizmin büyüklenmeci boyutuna ilişkin ele alarak değerlendirmelerinin klinik açıdan yararlı olacağı düşünülmüştür. Bununla birlikte narsisizmin büyüklenmeci boyutuna ilişkin açıklamaların, aldatma sorununun erken dönemde karşılanamayan kendilik nesnesi ihtiyaçlarından kaynaklanabileceği ve aldatmanın bu ihtiyaçların giderilmesine yönelik olabileceği düşünülmekte ve çalışmanın bu yönüyle de alanyazına önemli ve orijinal katkılar sağlayacağı varsayılmaktadır. Bu çalışmada evli bireylerin aldatma eğilimi ile büyüklenmeci narsisistik kişilik özellikleri arasındaki ilişkiye 1şık tutmak hedeflenmektedir. 18 yaş ve üstü, en az bir yıl süreyle evli bireylerin büyüklenmeci narsisistik kişilik özelliklerinin aldatma eğilimlerini etkileyeceği öngörülmektedir. Bu doğrultuda, araştırmada evli bireylerin aldatma eğilimi ile büyüklenmeci narsisistik kişilik özellikleri arasındaki ilişkinin incelenmesi amaçlanmıştır. Araştırmada aşağıda belirtilen araştırma sorularına yanıt aranacaktır.

- Evli bireylerin aldatma eğilimi ile büyüklenmeci narsisistik kişilik özellikleri arasında anlamlı bir ilişki var mıdır?

- Evli bireylerin aldatma eğilimi puanları cinsiyetlerine bağlı olarak farklılaşmakta mıdır?

- Evli bireylerin büyüklenmeci narsisistik kişilik özellikleri cinsiyetlerine bağlı olarak farklılaşmakta mıdır? 


\section{Yöntem}

Araştırmada iki veya daha fazla sayıda değişken arasında birlikte değişimin varlığını ve derecesini belirlemeyi hedefleyen nicel modelde ilişkisel tarama deseninden yararlanılmıştır (Karasar, 2011).

\section{Çalışma Grubu}

$\mathrm{Bu}$ araştırmanın evreni, İstanbul'da yaşayan evli bireylerden meydana gelmiştir. Örnekleme dahil edilen katılımcılar, 20 yaş ve üstü, en az bir yıl süreyle evli olmalarına dikkat edilerek çalışmaya alınmış 60 kişidir. Veri toplama araçlarının kendi kendine doldurulması gerektiği için katılımcıların en az ilkokul mezunu olması şartı aranmıştır. İstanbul'da yaşayan evli bireylerden oluşan örneklemden yararlanarak evli bireylerin aldatma eğilimleri ve büyüklenmeci narsisistik kişilik özellikleri incelenmiş olup kartopu veri toplama yöntemi kullanılmıştır. Veriler, Aralık 2019 - Ocak 2020 tarihleri arasında elde edilmiştir. Katılımcılara zarflar içinde ulaştırılan veri toplama araçları, gizliliği sağlamak için kapalı olarak teslim alınmıştır.

\section{Veri Toplama Araçları}

\section{Kişisel Bilgi Formu}

Araştırmacı tarafından düzenlenen kişisel bilgi formunda araştırmanın alt amaçlarına yönelik veri elde etmek adına yaş, cinsiyet, eğitim durumu, evlilik yılı ve evlilik biçimini içeren sorular yer almaktadır.

\section{Aldatma Eğilimi Ölçeği (AEÖ)}

Polat (2006), Aldatma Eğilimi Ölçeği'ni, evli bireylerin aldatma eğilimlerini değerlendirmek maksadıyla geliştirmiştir. 30 maddeden oluşan bu ölçek, beşli Likert tipindedir. 30 maddeden 18'i olumlu (aldatma eğilimini ölçen) 12'si ise olumsuz yönlüdür (aldatma olarak kabul edilmeyen davranışlar) ve ters puanlanır. Ayrıca 4, 9, 10, 11, 14, 16, $17,18,20,23,27$ ve 28. maddeler ise ters puanlanmaktadır. Her bir madde 
göz önüne alınarak katılımciların "Tamamen Katılıyorum", "Katılıyorum", "Kararsızım", "Katılmıyorum" ve "Kesinlikle Katılmıyorum" ifadelerinden, kendilerini en iyi ifade eden seçeneği işaretlemeleri beklenmektedir. "Tamamen Katılıyorum" ifadesi 5 puan alırken, "Kesinlikle Katılmıyorum" ifadesi 1 puan almaktadır. Ölçekten alınan en düşük puan 30 ve yüksek puan 150'dir. Ölçekten elde edilen skorun yüksekliği, aldatma eğilimindeki artışa işaret etmektedir. Ölçeğin Cronbach alfa katsayısı ,95; iki yarı güvenirlik de ,95 olarak bulunmuştur. Ölçeğin geçerlilik çalışması yağılmış ve geçerli bir ölçek olduğu saptanmıştır. Kantarcı (2009), ölçeğin Cronbach alfa güvenirlik katsayısı .92 olarak hesaplamıştır. Ölçeğin güvenirliği yapılan çalışmadan elde edilen Cronbach Alfa iç tutarlılık katsayıları ile incelenmiş ve iç tutarlılık katsayısı ,85 olarak bulunmuştur (Polat, 2006).

\section{Narsistik Kişilik Envanteri - NKE (Narcissistic Personality Inventory - NPI-16)}

Büyüklenmeci narsisiszmin ölçülmesi amaciyla 16 maddelik Narsistik Kişilik Envanteri kullanılmıştır. Raskin ve Hall (1979) tarafından 54 madde halinde geliştirilen ölçeğin daha sonra 40 maddeden oluşan formu geliştirilmiştir (Raskin ve Terry, 1988). 2005 yılında Ames ve arkadaşları tarafından 16 madde ile yeniden düzenlenen NKE yaygın olarak kullanılmaya başlanmıştır. Özbildirime dayalı ölçeğin yönergesinde katılımclardan her bir tutum çifti içinden kendilerine en uygun olan önermeyi işaretlemeleri istenmiştir. Yüksek puanlar büyüklenmeci narsisizm düzeyinin artmasına işaret etmektedir. NKE'nin 16 soruluk formunun Türkçe geçerlik-güvenirlik çalışması Atay (2009) tarafından gerçekleştirilmiştir. Ölçeğe katkı sağlamadığı anlaşılan dört ifadede revizyona gidilmesinin ardından ölçeğin güvenirlik katsayısı olan Cronbach alfa 37 değerinin ,63 olduğu tespit edilmiştir. Yapılan faktör analizi sonucunda ölçeğin orijinal haline uygun biçimde altı faktör yapısına sahip olduğu ve geçerli bir ölçek olduğu gözlenmiştir. Alt faktörler otorite, kendine yeterlik, üstünlük, teşhircilik, hak iddia etme ve sömürücülüktür. Ölçeğin güvenirliği yapılan çalışmadan elde edilen Cronbach Alfa iç tutarlılık katsayıları ile incelenmiş ve iç tutarlılık katsayısı 0,82 olarak bulunmuştur. Alt ölçeklerin iç tutarlılık katsayıları 
otorite $(a=, 76)$, kendine yeterlik ( $a=, 77)$, üstünlük $(a=, 77)$, teşhircilik $(a=, 80)$, hak iddia etme $(a=, 81)$ ve sömürücülük $(a=, 81)$ şeklindedir.

\section{Araştırma Etiği}

Araştırmaya başlamadan önce çalışmanın konusu belirlenmiş ve araştırmaya uygun olan ölçekler taranmıştır. Karar kılınan veri toplama araçlarının kullanılabilmesi için gerekli olan izinler ölçeklerden sorumlu araştırmacılardan alınmıştır. Ardından katılımcılara zarflar içinde ulaştırılan veri toplama araçları, gönüllülük esası ve etik kurallar dikkate alınarak doldurtulmuş, gizliliği sağlamak için kapalı olarak teslim alınmıştır.

\section{Verilerin Analizi}

İstatistiksel incelemeler ve yorumlamalar; $p<, 05$ anlamlılık düzeyine göre değerlendirilmiştir. Öncelikle verilerin normal dağılıp dağılmadığı ve uç değerlerin varlığı incelenmiştir. Ardından, çoklu parametrik istatistiğin normallik, eşvaryanslılık, doğrusallık gibi birtakım sayıltılarını karşılayıp karşılamadığı incelenmiştir (Tabachnick ve Fidell, 2013). Araştırmaya katılan fakat ölçekleri tamamlamadığı tespit edilen 4 katılımcıya ait veriler araştırma örnekleminden çıkarılmıştır. Bu katılımcıların araştırmaya dahil edilmemesi sonucu geriye 60 katılımcı kalmıştır. Araştırmanın analizleri 60 kişiden elde edilen veriler üzerinden yapılmıştır. Sosyodemografik verilere göre aldatma eğilimi ve büyüklenmeci narsisizm $\mathrm{t}$ testi yapılarak karşılaştırılmış ve aldatma eğilimi ile büyüklenmeci narsisizm ilişkisine bakmak için korelasyon analizi yapılmıştır.

\section{Bulgular}

$\mathrm{Bu}$ bölümde çalışmanın amacına yönelik olarak yürütülen analizlerin bulgularına yer verilmiştir. Aldatma eğilimi ile büyüklenmeci narsisizm ve alt boyutları puan ortalamaları ve standart sapma değerleri verildikten sonra değişkenler arasındaki ilişkilerin belirlenebilmesi için Pearson Momentler Çarpımı Korelasyon analizi uygulanmıştır. Cinsiyete göre 
aldatma eğiliminde ve büyüklenmeci narsisizm düzeyinde farklılaşma olup olmadığını belirlemek adına bağımsız örnek $t$ testi yapılmıştır.

Tablo 1. Aldatma Ĕ̆ilimi Ölçeği, Narsisistik Kişilik Özellikleri Envanteri Alt Boyut Puanları ile İlgili Tanımlayıcı İstatistikler

\begin{tabular}{llll}
\hline Değişkenler & $\mathbf{N}$ & $\bar{X}$ & SS \\
\hline 1. Aldatma Eğilimi & 60 & 112,25 & 28,13 \\
2. Otorite & 54 &, 85 &, 49 \\
3. Teşhircilik & 51 & 1,00 &, 63 \\
4. Sömürücülük & 52 & 1,65 &, 79 \\
5. Hakiddia etme & 54 & 1,59 &, 63 \\
6. Kendine Yeterlik & 55 & 1,76 &, 83 \\
7. Üstünlük & 52 & 1,13 & 1,1 \\
8. Büyüklenmeci Narsisizm & 60 & 7,08 & 3,1 \\
\hline
\end{tabular}

Aldatma eğilimi ölçeği toplam puanı incelendiğinde örneklemi oluşturan 60 katılımcının verileri SPSS ile hesaplanmış olup $(\bar{X}: 112,25$; SS:28,13) sonucuna erişilmiş̧ir.

Narsisistik kişilik özellikleri envanteri alt boyutlarına ilişkin ortalama puanlar incelendiğinde, örneklemi oluşturan katılımcının verileri SPSS ile hesaplanmış olup; otorite ( $\bar{X}:, 85 ;$ SS:49), teşhircilik( $\bar{X}: 1,00 ;$ SS:,632), sömürücülük ( $\bar{X}: 1,65$; SS:,78), hak iddia etme ( $\bar{X}: 1,59$; SS:,63), kendine yeterlik ( $\bar{X}: 1,76$; SS:,83), üstünlük ( $\bar{X}: 1,13 ; S S: 1,10)$ ve büyüklenmeci narsisizm ( $\bar{X}: 7,08 ;$ SS:3,08) puanlarına sahip olduğu gözlenmiştir.

Tablo 2. Aldatma Ĕ̆ilimi ve Büyüklenmeci Narsisizm Arasındaki İlişkilerin İncelenmesi

\begin{tabular}{lcccccccc}
\hline Değişken & $\mathbf{1}$ & $\mathbf{2}$ & $\mathbf{3}$ & $\mathbf{4}$ & $\mathbf{5}$ & $\mathbf{6}$ & $\mathbf{7}$ & $\mathbf{8}$ \\
\hline 1. Aldatma Eğilimi & - & & & & & & & \\
2. Otorite &, 114 & - & & & & & & \\
3. Teşhircilik &,- 007 &, 067 & - & & & & & \\
4. Sömürücülük &,- 021 &, 207 &, 280 & - & & & & \\
5. Hak iddia etme &, $387^{* *}$ &, 228 &, 000 &, 068 & - & & & \\
6. Kendine Yeterlik &, 192 &, 228 &,- 186 &,- 113 &, 408 & - & & \\
7. Üstünlük &,- 065 &, $284^{*}$ &, 144 &,- 201 &,$- 277^{*}$ &, 498 & - & \\
8. Büyüklenmeci Narsisizm &, 122 &, $576^{* *}$ &, $489^{* *}$ &, $563^{* *}$ & $, 415^{* *}, 215,498^{* *}$ & \\
\hline
\end{tabular}

Not. ${ }^{* *} p<.001,{ }^{*} p<.05$.

Tablo 2'den anlaşılacağı üzere, aldatma eğilimi ile büyüklenmeci narsisizm $(r=, 12, p>, 05)$ arasında anlamlı ilişki bulunamamıştır. Diğer taraftan, büyüklenmeci narsisizmin 6 alt boyutundan olan hak iddia etme ile aldatma eğilimi $(r=, 39, p<, 001)$ arasında pozitif yönde anlamlı ilişki 
görülmektedir. Katılımcıların hak iddia etme puanları arttıkça aldatma eğilimi puanları da artış göstermektedir.

Tablo 3. Örneklem Grubunda Yer Alan Evli Bireylerin Cinsiyetleri Açısından Aldatma Ĕ̆ilimine Yönelik Aldıkları Puanlar

\begin{tabular}{llllllll}
\hline Değişken & Cinsiyet & $\mathbf{N}$ & $\bar{X}$ & $S S$ & $t$ & $S D$ & $p$ \\
\hline Aldatma Eğilimi & Kadın & 30 & 120,93 & 24,28 & \multirow{2}{*}{2,494} & \multirow{2}{*}{58} & \multirow{2}{*}{.016} \\
Levene $F=1.25, p=.26$ & Erkek & 30 & 103,56 & 29,40 & & & \\
\hline Not. ${ }^{* *} p<, 001,{ }^{*} p<.05$. & & & & & & &
\end{tabular}

Tablo 3'te kadın ve erkek katılımclların aldatma eğilimine ait toplam puan ortalamaları ve bu puanlara ait standart sapma değerleri yer almaktadır. Bulgular ele alındığında; katılımcıların cinsiyetleri açısından aldatma eğilimi puanları istatistiksel olarak anlamlı biçimde farklılaşmaktadır; kadın katılımcıların aldatma eğilimi puan

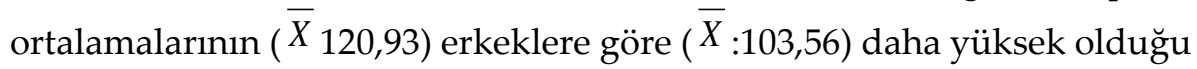
görülmektedir (t0.05: 58 $=2,494 p<, 05)$.

Tablo 4. Örneklem Grubunda Yer Alan Evli Bireylerin Cinsiyetleri Açısından Büyüklenmeci Narsisizme Yönelik Aldıkları Puanlar

\begin{tabular}{lccccccc}
\hline Değişken & Cinsiyet & $\mathbf{N}$ & $\bar{X}$ & $S S$ & $t$ & $S D$ & $p$ \\
\hline Büyüklenmeci Narsisizm & Kadın & 30 & 7,57 & 2,70 & & & \\
& Erkek & 30 & 6,60 & 3,40 & & & \\
Levene $F=1.25, p=.26$ & & & & & & & \\
\hline Not. ${ }^{* *} p<.001,{ }^{*} p<.05$. & & & & & & &
\end{tabular}

Tablo 4'te kadın ve erkek katılımcıların büyüklenmeci narsisizme ait puan ortalamaları ve bu puanlara ait standart sapma değerleri yer almaktadır. Bulgular ele alındığında; katılımcıların cinsiyetleri açısından büyüklenmeci narsisizm puanlarının istatistiksel olarak anlamlı biçimde farklılaşmadığ 1 görülmektedir ( $\left.t_{0.0558}=1,220 p>, 05\right)$. Bu sonuçlar göz önüne alındığında; kadın ve erkek bireylerin büyüklenmeci narsisizm puanlarının benzer düzeyde oldukları, birbirlerinden anlamlı biçimde farklılaşmadıkları söylenebilir.

Sonuç, Tartışma ve Öneriler 
Söz konusu çalışmada katılımcıların cinsiyetleri açısından aldatma eğilimi puanları istatistiksel olarak anlamlı biçimde farklılaşmaktadır; kadın katılımcıların aldatma eğilimi erkeklere göre daha yüksek bulunmuştur. Bununla ilgili ülkemizde yapılan bir tez çalışmasında mevcut çalışma bulgularıyla uyumlu olarak kadın katılımcların aldatma eğilimi erkeklere göre daha yüksek bulunmuştur (Seyfi, 2017). Diğer yandan cinsiyet açısından aldatma eğiliminin farklılık göstermediği tespit edilmiştir (Zandbergen ve Brown, 2015; Kato, 2014; Tortamış, 2014; Çavuşoğlu, 2011). Buna ek olarak erkeklerin kadınlara göre daha fazla aldatma davranışında bulunduğu belirtilmektedir (Atkins, Baucom ve Jacobson, 2004). Aldatma nedenleri açısından bakıldığında erkeklerin kadınlara göre daha basit nedenler sonucunda (yenilik arayışı, anlık haz duygusu, ciddi ilişki istemeyen kadınların varlığı vb.) aldatma eğilimi gösterdikleri saptanmıştır (Norment, 1988). Öte yandan bazı çalışmalar erkek ve kadınların aldatma eğiliminin benzer olduğunu göstermektedir. Araştırmanın birinde kadınların \%40, erkeklerin \%60 oranında aldatma davranışında bulunduğu vurgulanmaktadır (Wetchler, 2005). Ancak bütün bunlara sebep olarak; dini inanç ve kültürel faktörleri de göz önünde bulundurmak önem arz etmektedir (Duba, Kindsvatter ve Lara, 2006). Bu bağlamda değerlendirildiğinde çalışmada kadın katılımcıların erkeklere göre aldatma eğiliminin yüksek olmasının kadının iş yaşamına katılımındaki artışı, sosyal çevredeki artışı ve katılımcı sayısının azlığı, örneklemin homojen dağılmaması gibi özellikler sayılabilir. Buna ek olarak erkeklerin çalışma hayatında uzun saatler bulunması, eve geç gelmesi, ilgi kaybı ve tatminsizlik kadınlarda aldatma eğilimini artırmış olabilir. Aldatma eğilimi açısından cinsiyete göre farklılıkları anlayabilmek için daha geniş kapsamlı örneklem ile yapılan kültürel çalışmalara ihtiyaç duyulmaktadır.

Literatüre bakıldığında evlilik dışı ilişki yaşayan kadınların erkeklere göre evliliklerinden aldıkları doyumun yetersiz olduğu; erkeklerin cinsellik sebebiyle, kadınların ise duygusal doyumsuzluğu giderme ihtiyacı sebebiyle aldatma davranışı gösterdiği saptanmıştır (Glass ve Wright, 1985). Burchell ve Ward (2011) kadınların duygusal aldatılma yaşamaktan, erkeklerin ise cinsel aldatılma yaşamaktan kayg1 duyduklarını ifade etmişlerdir. Araştırmanın birinde kadınların 
aldatmayı erkeklere göre ahlak dışı bulduğu belirlenmiştir. Buna ek olarak cinselliğin kadınlar için erkeklere göre daha zayıf bir arzu olduğu ve kontrol edilebileceği; erkekler için ise tatmin edilmesi gereken doğal ve kontrol edilemeyen bir ihtiyaç olduğu vurgulanmaktadır (Knodel, Low, Saengtienchai ve Lucas, 1997). Aldatmayı etkileyen faktörlerden biri de çalışma yaşamı ve daha fazla kişiyle iletişime geçme olarak değerlendirilmektedir. Tarihsel olarak kadınlara göre daha fazla çalışma yaşamında bulunduğundan erkeklerin aldatma potansiyelinin daha yüksek olduğu öne sürülmektedir (Schwartz ve Young, 2009). Günümüzde kadınların da çalışma hayatına yoğun ve hızlı bir şekilde katılımına bağlı olarak aldatma eğilimi oranlarında bir farklılaşma olduğu belirtilmektedir (Atkins, Baucom ve Jacobson, 2001). Yapilan bir çalışmada aldatma eğilimi ile cinsiyet arasında anlamlı bir ilişki olduğu, erkeklerin aldatma eğiliminin kadınlara oranla daha fazla olduğu bulunmuştur (Kankaya, 2015). Türkiye'de sınırlı sayıda araştırma bulunduğundan aldatma eğilimi üzerinde cinsiyetin nasıl bir etkide bulunduğu net bir sonuca bağlanamamaktadır. Bu konuda daha fazla çalışmaya ihtiyaç vardır.

Çalışmada kadın ve erkek bireylerin büyüklenmeci narsisizm puanlarının benzer düzeyde oldukları, birbirlerinden anlamlı biçimde farklılaşmadıkları saptanmıştır. Literatüre bakıldığında yapılan bir çalışmada erkek katılımcılarda aşırı izin verici/sınırsız ebeveynlik algısının kadınlardan daha fazla gösterildiği saptanmıştır (Tortamış, 2014). Kız çocukların bağımlı şekilde büyümesinin ve erkek çocukların özgürlügüne izin verilmesinin bu konuda büyük payının olduğu vurgulanmaktadır (Crawford ve Unger, 2004). Hak iddia etme ile zedelenmiş sınırların ilişkisi düşünüldüğünde mevcut çalışmada kadın ve erkek katılımcılar arasında büyüklenmeci narsisizmin farklılık göstermemesinin literatürle uyumlu olmadığı görülmektedir. Bu durumun kısıtlı örneklem sayısından kaynaklandığı, bu konuda daha fazla sayıda katılımcı ile değişkenlerin ilişkisinin incelenmesinin daha doğru olacağı düşünülmektedir. Büyüklenmeci narsisizmin hak iddia etme dışındaki alt boyutları ile aldatma eğilimi arasında ilişki bulunamaması üstünlük, sömürücülük, otorite, teşhircilik ve kendine yeterlik narsisistik özelliklerin katılımcılar tarafından gizlenmesiyle ilişkili olabilir. 
Çalışma sonucunda aldatma eğilimi ile büyüklenmeci narsisizm arasında anlamlı ilişki bulunamamıştır. Diğer taraftan, büyüklenmeci narsisizmin altı alt boyutundan olan hak iddia etme ile aldatma eğilimi arasında orta derecede kuvvetli, pozitif yönde anlamlı ilişki saptanmıştır. Hak iddia etme kişilik boyutu arttıkça aldatma eğilimi de artış göstermektedir. İlgili literatüre bakıldığında narsisistik kişilik özelliklerinin gelişiminde bazı ebeveynlik biçimlerinin ön planda olduğu görülmektedir (Young, Klosko ve Weishaar, 2003). Patolojik narsisizm düzeyi yüksek bireylerin ebeveynleri tarafından "özel" hissettirilen, sınırları zedelenmiş bireyler olduğu vurgulanmaktadır. Sınırları çizmekte güçlük çeken bakım veren (çoğunlukla anne) çocuğun tolerans, paylaşımda bulunma ve sabır gösterme gibi önemli deneyimleri öğrenme fırsatını engellemektedir. Aşırı izin verici tutum gösterilen çocuk aracılığıyla ebeveyn, kendi statü ve tanınma ihtiyaçlarını gidermeye çalışmaktadır. Bunu çocuğundan yüksek beklentiler içinde bulunarak, yönlendirici ve otoriter davranışlarıyla yönetmektedir. Diğer ebeveyn olarak babanın (genellikle) mesafeli, uzak, pasif, reddeden, eleştiren, talep eden ve istismarcı olduğu durumlarda da çocuk narsisistik kişilik özellikleri geliştirmektedir (Paas, 2020). Böyle bir ortamda büyüyen çocuğun hak görme özelliği gelişeceğinden yetişkinlik döneminde romantik yakın ilişkilerde aldatmayı da bir ihtiyacını karşılamak amacıyla kendine hak görebilir. Dolayısıyla araştırmada hak iddia etme ile aldatma eğilimi arasındaki korelasyon ilişkisi literatürle uyumludur denilebilir. Buna ek olarak büyüklenmeci narsisism ile aldatma eğilimi arasında ilişki bulunamamasının örneklem sayısının düşük olması ile ilgili olabileceği düşünülmektedir. Bunun yanı sıra bazı narsisistik bireylerin daha kırılgan olması sebebiyle kendini gizleyebileceğinden envanterdeki soruları yönlendirebileceği düşünülmektedir. Bu sebeple sonraki çalışmaların kırılgan narsisistik yapıyla da ilişkilendirilmesi literatüre katkı sunabilir.

Young ve diğ., (2003) narsisistik kişilik özellikleri gösteren bireylerin erken dönemde ebeveynleri tarafından karşıt tutumlara maruz kaldığını belirtmektedir. Bir ebeveyn değerlerini yükseltirken diğer ebeveyn kendilerini görmezden gelmekte ya da değerlerini düşürmektedir. Şema terapi modeli çerçevesinde bakıldığında narsisistik patolojinin kaynağında hak görme/büyüklük şemasının iki farklı şekilde görüldüğü vurgulanmaktadır (Young ve diğ., 2003). Mutlak hak görme erken 
dönemde ebeveynler tarafından şımartılma, sınırların zedelenmesi sonucunda ortaya çıkmaktadır. Bu şekilde yetişen birey her şeyi istediği zaman elde edebileceğini düşünmektedir. $\mathrm{Bu}$ durumda kişide hak görme/büyüklük şeması gelişir. Diğer yandan altta yatan duygusal yoksunluk ve kusurluluk şemalarını telafi etmek amaciyla hak görme/büyüklük şeması gelişebilmektedir. Sınırları zedelenmiş çocuk isteklerini gerçekleştirmek için herhangi bir engel görmez, istediğini her an elde edebileceğini düşünmektedir. Duygusal yoksunluk ve kusurluluk şemalarının aşırı telafisi sebebiyle gelişen hak görme/büyüklük şemasının kökeninde üzgün, yalnız, kusurlu ve değersiz birey bulunmaktadır (Young ve Klosko, 1994). Bu şekilde ebeveynleri tarafından kötü erken dönem deneyimleri edinmiş bireylerin uyumsuz şemaları yetişkinlik döneminde mahremiyet, şefkat ve ilgi barındıran partner ilişkilerinde sergilenmektedir (Wright, Crawford ve Sebastian, 2007). Romantik ilişkiler içerisinde eşlerin şemaları arasında uyum bulunmadığında sorunlar ortaya çıkmaktadır (Yoosefi, Etemadi, Bahrami, Fatehizade ve Ahmadi, 2010).

Bu bağlamda yapılan çalışmalara bakıldığında kadınlarda ebeveynleri tarafından aşırı izin verici/sınırsız ebeveynlik algısının aldatma eğilimi ile ilişkili olduğu belirtilmektedir. Erkeklerde ise anneye dair aşırı izin verici/sınırsız ebeveynlik algısı ile babaya dair aşırı izin verici/sınırsız ebeveynlik ve cezalandırıcı ebeveynlik algısının aldatma eğilimini açıkladığ1 vurgulanmaktadır (Young ve Klosko, 2013). Bu ebeveynlik tarzlarının birey üzerinde hak iddia etme erken dönem uyumsuz şema gelişimine sebep olduğu yukarıda açıklanmıştır. Bu kapsamda mevcut çalışma sonucunda hak iddia etme ile aldatma eğilimi arasında çıkan pozitif ilişki bulgusu literatürle paraleldir. Aşırı izin verici/sınırsız ebeveynlik biçiminin aldatma eğilimini yordaması oldukça anlamlıdır.

Erken dönemde ebeveynleri tarafından sinır koymada sorunları olan bireylerin yetişkinlik döneminde sınır sorunları yaşaması gayet muhtemeldir. Otokontrol erken dönemde ebeveynlerden öğrenilen bir beceridir. İzin verici ebeveynlerle büyüyen kişiler diğerlerine göre bencil olmaya eğilimlidirler ve bunun yanında sorumsuzluk, bağımlılık ve sıklıkla dürtüleri kontrol etmede zorlanma yaşamaktadırlar. Bunun yanı sıra bu kişilerin, cinsel arzu ve hazzı erteleme konusunda da benzer sorunlar yaşayabileceği, aşırı yeme, madde kullanımı, sigara ya da cinsel 
aktivitelere aşırı düşkünlük şeklinde semptomlar görülebileceği vurgulanmaktadır (Young ve Klosko, 2003). Yapılan bir çalışma sonucuna göre dürtüsellik ve hazzı erteleme sorununun aldatmayı yordadığ1 belirlenmiştir (Buss ve Shackelford, 1997). Bu kapsamda mevcut çalışma sonucunda hak iddia etme ile aldatma eğilimi arasında çıkan pozitif ilişki bulgusu literatürle uyumludur denebilir.

Araştırmanın sınırlılıkları ve bulgularına yönelik şu öneriler geliştirilmiştir:

1. Çalışmanın sınırlılıklarına bakıldığında; ilk olarak iradi yöntemle seçilen katılımcıların sayısının genellenebilirliğinin düşük olduğu ve kullanılan ölçeklerin güvenirlik ve geçerlik düzeylerinin bu örneklem sayısı ile sınırlı olduğu düşünülmektedir. Buna öneri olarak sosyodemografik değişkenlerin çeşitliliğinde artış sağlanmasının örneklemin popülasyonu daha gerçekçi yansıtmasını sağlayacağı ve genellenebilirliği artıracağı düşünülmektedir.

2. Bir diğer sınırlılık olarak ölçeklerin öz bildirime dayalı olmasının, büyüklenmeci narsist bireylerin hak iddia etme dışındaki boyutlara bağlı olarak savunucu bir tutum takınmalarının kendilerini iyi sunmak amaçlı aldatma eğilimi ölçeği sorularına samimi yanıtlar vermelerine engel olabileceği düşünülmektedir.

3. Adatma eğilimi ölçeğindeki soruların gayet açık ve net bildirime dayalı olması bazı çekincelere yol açmış olabileceğinden yapılacak diğer çalışmalarda bireysel görüşmeler sağlanarak kapsamlı bilgilere ulaşılması sağlanabilir.

4. Yapılan bu çalışma korelasyonel bir çalışmadır. Bu nedenle nedensellik değil ilişkisellik bağlamında değerlendirilmelidir. Bu kapsamda da araştırmanın sınırlılıklarını gidermek anlamında sonuçları etkileyen değişkenler kontrol edilmeli ve nedensel çıkarımlar yapılabilmesi sağlanmalıdır. Sonuç olarak aldatma eğilimi ile büyüklenmeci narsisizm ilişkisini ele alacak daha kapsamlı ve geniş örneklemli yeni çalışmalara ihtiyaç duyulmaktadır. 
EXTENDED ABSTRACT

\title{
A Study on the Link between the Tendency to Cheat and Adaptive Narcissistic Personality Characteristics in Married Individuals
}

\author{
Lütfiye Kaya Cicerali- Arzu Büyük \\ Nisantasi University
}

Literature shows that in Turkey cheating tendency and psychopathology assocaition is a domain rich in research, while personality disorders have not yet sufficiently been linked to cheating. This study aimed at filling this gap, looking at the early childhood maladaptive schemas of narcissistic grandiosity and their link to cheating tendency. Unmet early childhood need of having a self object is assumed to be the original cause of the emergence of cheating tendency in adulthood. In other words, cheating is hypothesized to be a means of satisfying the unmet need to possess a selfobject in narcissists. Feelings of entitlement is an emphasized subfactor of the maladaptive early childhood schema leading to narcissistic personality disorder. It developes through overpermissive, emotionally deprived parenting (Tortamıs, 2014).

The data was collected between December 2019 and January 2021. Participants were 60 individuals living in Istanbul, at full 18 years of age or older, and currently married for at least 1 -year. They were reached by a snowball availability sampling method, were given the research battery in open envelopes which were required to be returned as closed for confidentiality issues. The following research questions were asked:

- Is there a significant relationship between cheating tendency and grandiose narcissism trait in married people?

- Do cheating tendency scores vary with gender of married people?

- Do grandiose narcissism trait scores vary with gender of married people?

For data collection personal information form, the Cheating Tendency Scale, and the Narcissistic Personality Inventory were used. The foremost was compiled by the researchers. Polat (2006) developed the Cheating Tendency Scale to assess the cheating proclivity of married people. It was 
made up of 30 items on a 5-point Likert scale. There were 18 items measuring cheating inclination, and 12 items measuring anti-cheating inclination that are reverse-coded. Narcissistic Personality Inventory (NPI-16) was developed by Raskin and Hall (1979) and originally included 54 items then revised and reduced to 16 items by Ames et al. (2005). It is on an ipsative scale where respondents were forced to choose between two alternative statements. Higher scores meant higher grandiose narcissism. Atay (2009) made the psychometric validation and reliability work into Turkish.

The results showed that the first research question was partially confirmable: There was no robust relationship (correlation) between overall grandiose narcissism and cheating tendency (Table 2). The t-test also showed that the cheating tendency level of people with inflated grandiose narcissism was not significantly higher than the ones with low level grandiose narcissism personality trait. However, between entitlement and cheating tendency there was a moderate correlation (Table 2). With regards to the second research question, women turned out to have significantly higher cheating tendency scores compared to men (Table 3). This is thought to be an offshoot of women's increased participation in work life and a parallell enlargement of their freedom as well as social circle, which might have together increased their flirting opportunity and tendency. This may also be related to the small unrandomized sample in this study. Men's spending more time at work, coming home late, and losing interest in their wives might also have contributed to women's self-reported cheating tendency levels.

The third research question concerned gender's role in moderating grandiose narcissism of married individuals (Table 4). Statistical tests revealed it is insignificant.

The results of this study did not reveal a significant relationship between grandiose narcissism and cheating tendency. On the other hand, a mediocre relationship between entitlement subfactor of narcissism and cheating tendency was observed: As entitlement increased cheating tendency increased, as well. If we analyze this against the previous literaure we see that some parenting behavious play striking role in emergence of narcissistic personality traits in children (Young, Klosko ve Weishaar, 2003). Pathological narcissism level increases if parents behave 
their children in such a way that they feel special. According to schema therapy it leads to impaired limits whereby children do not tolerate, learn sharing and develop patience.

This survey study contributed to Turkish psychology literature in relevant lines such as clinical psychology and marital therapy by means of linking cheating tendency and grandiose narcissism personality traits of married individuals. Schema therapy conceptualization of grandiose narcissism was used. Gender differences in grandiose narcissism and cheating tendency were also checked as secondary hypotheses. Although grandiose narcissism did not differ according to gender, cheating tendency was seen higher in women. The sample was not representative, random, with a big enough size and heterogeneity, therefore the results are not generalizable. Yet, science is accumulation of data and the results of this research may be used as a corroborative information for more representative research.

\section{Kaynakça / References}

Arrindell, W. A. and Emmelkamp, P. M. (1986). Marital adjustment, intimacy and needs in female agoraphobics and their partners: A controlled study. The British Journal of Psychiatry, 149(5), 592-602.

Atkins, D. C., Baucom, D. H. and Jacobson, N. S. (2001). Understanding infidelity: Correlates in a national random sample. Journal of family psychology, 15(4), 735.

Atwood, J. D. and Schwartz, L. (2002). Cyber-sex: The new affair treatment considerations. Journal of Couple \& Relationship Therapy, 1(3), 37-56.

Bagarozzi, D. A. (2014). Enhancing intimacy in marriage: A clinician's guide. Routledge, New York: Elsevier.

Bowlby, J. (1951). Maternal care and mental health (Vol. 2). Geneva: World Health Organization.

Bradbury, T. N. and Fincham, F. D. (1988). Individual difference variables in close relationships: A contextual model of marriage as an integrative framework. Journal of Personality and Social Psychology, 54(4), 713.

Brunell, A. B and Campbell, W. K. (2011). Narcissism and romantic relationships. The handbook of narcissism and narcissistic personality disorders: Theoretical approaches, empirical findings and treatments, 344-350. 
Burchell, J. L. and Ward, J. (2011). Sex drive, attachment style, relationship status and previous infidelity as predictors of sex differences in romantic jealousy. Personality and Individual Differences, 51(5), 657-661.

Buss, D. M. and Shackelford, T. K. (1997). From vigilance to violence: Mate retention tactics in married couples. Journal of personality and social psychology, 72(2), 346.

Crawford, M. and Unger, R. (2004). Women and gender: A feminist psychology. McGraw-Hill.

Çavuşoğlu, H., Kaya, R. A., Türkmenoğlu, O. N. ve Aydin, Y. (2010). Value of early unilateral decompressive craniectomy in patients with severe traumatic brain injury. Ulus Travma Acil Cerrahi Derg, 16(2), 119-124.

Çavuşoğlu, Z. Ş. (2011). Bağlanma stilleri, evlilik uyumu ve aldatma eğilimi arasındaki ilişkinin incelenmesi. Yayımlanmamış yüksek lisans tezi. Maltepe Üniversitesi Sosyal Bilimler Enstitüsü, İstanbul.

Dickinson, K. A. and Pincus, A. L. (2003). Interpersonal analysis of grandiose and vulnerable narcissism. Journal of personality disorders, 17(3), 188-207.

Duba, J. D., Kindsvatter, A. and Lara, T. (2008). Treating infidelity: Considering narratives of attachment. The Family Journal, 16(4), 293-299.

\section{Kaynakça Bilgisi / Citation Information}

Kaya Cicerali, L. ve Büyük, A. (2021). Evli bireylerin aldatma eğilimi ile büyüklenmeci narsisistik kişilik özellikleri arasındaki ilişkinin incelenmesi. OPUS- Uluslararası Toplum Araştırmaları Dergisi, 18(42), 5230-5249. DOI: 10.26466/opus.936933. 